\title{
Spore-like bodies in some early Paleozoic acritarchs: Clues to chlorococcalean affinities
}

\author{
Józef Kaźmierczak and Barbara Kremer \\ Acta Palaeontologica Polonica 54 (3), 2009: 541-551 doi: http://dx.doi.org/10.4202/app.2008.0060
}

We present discoveries of internal bodies in problematic Silurian and Devonian organic-walled microfossils classified traditionally as polygonomorph, acanthomorph, sphaeromorph, and herkomorph acritarchs. These bodies are comparable with reproductive structures (auto- and/or aplanospores) of modern unicellular green algae (Chlorococcales). Our findings suggest that many of these microfossils may represent asexually reproducing (sporulating) vegetative cells of chlorococcalean algae. The presence of spore-like bodies in the studied acritarchs supports earlier suggestions, based on ultrastructural and biomarker studies, that some acritarchs can be affined with green algae.

Key words: Acritarchs, microfossils, Chlorococcales, phytoplankton evolution, Paleozoic.

Józef Kaźmierczak [jkaz@twarda.pan.pl] and Barbara Kremer [kremer@twarda.pan.pl], Institute of Paleobiology, Polish Academy of Sciences, Twarda 51/55, PL-00818 Warsaw, Poland.

This is an open-access article distributed under the terms of the Creative Commons Attribution License (for details please see creativecommons.org), which permits unrestricted use, distribution, and reproduction in any medium, provided the original author and source are credited. 